Abbreviated Key Title: Sch J Agric Vet Sci

ISSN 2348-8883 (Print) | ISSN 2348-1854 (Online)

Journal homepage: https://saspublishers.com/sjavs/

\title{
The Training Mode of the New Rural People
}

\author{
Zheng Yongwen", Wang Guoqing, Zhang Youli, Xu Xiaodan, Li Ying
}

Heilongjiang Bayi Agricultural University, Daqing City, Heilongjiang Province, China

DOI: $\underline{10.36347 / \text { sjavs.2020.v07i06.004 }}$

| Received: 07.06.2020 | Accepted: 15.06.2020 | Published: 24.06 .2020

*Corresponding author: Zheng Yongwen

Abstract

Review Article

With the rapid development of social economy and education concept, ideological and political education and mass entrepreneurship and innovation education has been widely used in the development of all walks of life. To a large extent, it has innovated the development mode of traditional industries, which makes the traditional industries glow with new vitality and vitality in the new situation. The development mode of "Ideological Education + agriculture" is conducive to the development of modern agriculture and has an important influence on the development of modern agriculture. This paper explores the mode of developing new farmers in rural areas. Through the mode of training new farmers, we should strengthen the combination of education and agriculture, and cultivate more innovative agricultural talents, so as to achieve the goal of rapid development and progress of China's modern agriculture.

Keywords: Ideological and Political Education, Entrepreneurship and innovation education, new farmer.

Copyright @ 2020: This is an open-access article distributed under the terms of the Creative Commons Attribution license which permits unrestricted use, distribution, and reproduction in any medium for non-commercial use (NonCommercial, or CC-BY-NC) provided the original author and source are credited.

\section{INTRODUCTION}

Under the concept of education, it is of great significance to promote the development and progress of agricultural modernization to vitalize the training mode of new farmers, grasp the development characteristics of "new farmers", and highlight the construction goal of agricultural talent team oriented by specialty, ability, quality and market. In the process of promoting the cultivation mode of new farmers, we should base on the situation of agricultural development, strengthen ideological and political education, entrepreneurship and innovation education and professional education, and promote the process of agricultural modernization with the help of "new farmers", so as to achieve the goal of agricultural modernization.

An analysis of the necessity of the application of the training mode of the new peasants

The effective combination of "mass entrepreneurship and innovation" personnel training and education mode and agricultural development has realized the goal of agricultural innovation and development, accelerated the process of agricultural modernization, helped to enhance agricultural output value and increase the economic benefits of agricultural products, and is of great significance for promoting the development of agricultural modernization. Mainly reflected in the following points:
(1) It is imperative for the development of the training mode of new farmers to revitalize the countryside

Combined with the current situation of rural economic development, the combination of agriculture and education concept presents a rapid development trend. According to the statistics of industrial information network, in 2018, the rural online retail sales reached 1775.24 billion yuan, accounting for $23.1 \%$ of the online retail sales, and showed a rapid growth trend. Under the background of the rapid development of the training mode of new farmers, the demand for "new farmers" is also increasing substantially. It is of great significance for promoting the development and progress of agricultural modernization to set up the construction goal of agricultural talents team oriented by specialty, ability, quality and market.

(2) Attention of governments at all levels to ideological and political education and mass entrepreneurship and innovation education

According to the investigation and research, in recent years, China's demand for agricultural talents Integrating Ideological and political education, entrepreneurship and innovation education and professional education have reached a new height. For a developing country, only the society of education can provide strength for the development of the country, 
and only the "new farmers" can contribute to the revitalization of the countryside. The new is an inexhaustible driving force for the development of a country and the spiritual source of national development. The revitalization and development of the countryside is of great importance to the country. It is an important decision for the development of socialism that our country has made the decision of Rural Revitalization and development early.

(3) Coordinated and complementary development mode of "Ideological Education + agriculture"

The application of ideological education, mass entrepreneurship and innovation education and professional education in the second industry and the third industry has greatly promoted the development of the second industry and the third industry, which makes the unbalanced development of the three industries increasingly. As the first industry, agriculture is also the basic industry for the development of social economy, the second industry and the third industry. The quality of agricultural development will play an important role in the development of social economy. It is of great significance to strengthen the combination of ideological education and new agriculture, and to promote the application of new farmer training mode in rural areas for promoting agricultural development and effectively realizing the goal of agricultural commercialization. At the same time, to improve the level of agricultural development and realize the coordination and complementarity of the three industries is of great significance to enhance the capacity and level of social and economic development in China.

\section{The important significance of the training mode of the new rural people}

Based on the revitalization of the countryside and strengthening the cultivation of talents.

The application of the training mode of Rural Revitalization of new farmers should be based on the fundamental goal of Rural Revitalization and improve the pertinence of talent training. From the perspective of rural economic development, in order to promote the innovative development of agriculture, we should do a good job in building a "new farmer" team, innovate the traditional agricultural development mode, and achieve the goal of agricultural modernization development by leading innovation, developing industry and cultivating high-level talents. Under the mode of cultivating new farmers, we should pay attention to the education of the thinking of agricultural people, grasp the development characteristics of the era of commodity economy, strengthen the close combination of agriculture and ideological education, expand the revitalization of rural areas with the help of Ideological and political ideas, entrepreneurship and innovation education, and improve the economic benefits and economic added value of agricultural products. The application and practice of new farmer training mode in education concept, based on the rural revitalization, promotes the rapid development of modern agriculture.

(2) Integrate educational ideas and do a good job in Ideological Education

Therefore, for the majority of agricultural people, we should not only pay attention to the cultivation of their own professional quality, but also pay attention to the cultivation of their own comprehensive ideological quality. According to the investigation and research, some agricultural people are prone to various problems in the process of actual entrepreneurship and work. In order to effectively improve and help the rural revitalization, we can provide a variety of Ideological and political concepts for agricultural people to choose for reference, so that students can choose their own ideas according to their own needs and development in the future, and cultivate comprehensive ability literacy.

(3) The development mode of new farmer to promote the development of Agriculture

There is a complete knowledge framework and theoretical basis for the training mode of Rural Revitalization of new farmers. If we neglect the study of Ideological and political education and mass entrepreneurship and innovation education in the development process of the training mode, the agricultural development will become blind. In the process of development, ideological and political education, mass entrepreneurship and innovation education and professional education are integrated, so as to give a clearer cognition to the cultivation mode of revitalizing new farmers in rural areas. Only after strengthening the ideological education can we ensure the correctness of development direction and training mode. In addition, the use of mass entrepreneurship and innovation education has the characteristics of high interaction and innovation, which can achieve innovation in the cultivation mode of farmers.

\section{CONCLUSION}

Under the background of Ideological and political education, mass entrepreneurship and innovation education and professional education, it is still in the exploratory stage to build a training model for Rural Revitalization of new farmers. In each training process, it is necessary to set up specific education courses according to the characteristic advantages of education concept and model characteristics, so as to realize a new rural revitalization of new farmers training model based on people and with ideological and political education and mass entrepreneurship education as the core concept And effectively cultivate the comprehensive ability and quality of "new farmers", input more excellent talents 
for social enterprises, and make contributions to the country.

Ideological and political education is not only a phenomenon of power, but also a social phenomenon. We should move from the authoritative world to the living world, and only to life can we understand life. Our duty is not only to prove the rationality of the reality, to cultivate people's satisfaction, but to give people the pursuit, more to be responsible for the future society. Our duty is not to maintain today, but to open up tomorrow, it is more important to give people crisis than satisfaction. Ideological and political educators should be confident and have the courage to pursue the scientific status of Ideological and political education through the practice of Ideological and political education.

\section{ACKNOWLEDGEMENTS}

Heilongjiang Provincial Higher Education Teaching Reform Project (Key Project)-Integrating Youth Red Dreams into "Double Innovation" Practical Teaching and Constructing a New Model of Agricultural College Talent Development (SJGZ20180044), Heilongjiang Provincial Department of Education, 2018. " We hope this new version of article will meet the requirement for publication.

\section{REFERENCES}

1. Tong Yong. Research on the reform of higher education and teaching in the context of mass entrepreneurship and innovation $[\mathrm{J}]$. Computer products and circulation. 2020; (1): 232

2. Wang Chao, Zhao long. Research on innovation and entrepreneurship education of university students of science and technology under the background of "mass entrepreneurship and innovation" [J]. Science and technology economy guide. 2019 (36): 93-94.

3. Zhu Lingwei. A study on the way to improve the employment quality of College Students [J]. Education modernization. 2019(58): 28-29.

4. Fu Haiyang, Cai Yupeng. Research on innovation and entrepreneurship education of College Students under the background of "mass entrepreneurship and innovation" $[\mathrm{J}]$. International public relations. 2020 (1): 133

5. $\mathrm{Gu}$ Mingyuan. Education DICTIONARY [M]. Volume 3. Shanghai: Shanghai Education Press; 1991.

6. Burns M. Distance education for teacher training: Modes, models and methods. Washington, DC: Education Development Center. 2011.

7. Cheng-qian XI. Research on the Path of Sports Development in China's Rural Areas under the New Urbanization Background. Journal of Nanjing Sports Institute. 2018(1):3.

8. CUI JQ, WANG S. Implementation route of national fitness in the process of urbanization. Shandong Sports Science \& Technology. 2017(1):17. 